\title{
Transabdominal amniocentesis in expectant management of preterm premature rupture of membranes: A single center prospective study
}

\author{
Veronika Fulova ${ }^{a}$, Eliska Hostinska ${ }^{a}$, Martina Studnickova ${ }^{a}$, Karel Humla , Jana Zapletalovab ${ }^{\mathrm{b}}$ Jan Halekc, Radovan Pilka ${ }^{\mathrm{a}}$
}

\begin{abstract}
Aims. The aim of this study was to evaluate the role of IL- 6 point-of-care test in amniotic fluid obtained from serial amniocentesis in expectantly managed women with PPROM between 24 and 34 weeks of gestation.

Methods. We conducted a prospective observational cohort study which included 62 pregnant women with PPROM in gestational weeks between $22+0$ and $34+0$. Women aged $>18$ years were eligible if they presented with PPROM and a singleton pregnancy. Only women who delivered at $>24.0$ weeks were included in the study. In all women, the maternal blood sampling and a transabdominal amniocentesis were performed at the time of admission prior to the administration of corticosteroids, antibiotics, or tocolytics, to rule out signs of chorioamnionitis. Maternal temperature, maternal serum C-reactive protein (CRP) and white blood cell (WBC) counts were assayed every subsequent day until delivery. Amniotic fluid was used for the clinical assessment (IL-6 point-of-care test, identification of microorganisms in the amniotic fluid. After one week of expectant management of PPROM, second amniocentesis with amniotic fluid sampling was performed in patients who did not deliver. For all newborns, medical records regarding neonatal morbidity and mortality were reviewed.

Results. In total, 62 women aged 19 to 41 years were recruited in the study. The mean gestational age at the time of PPROM was $31+0$, the mean gestational age at labor was $32+1$, and the median time from PPROM to childbirth was $112 \mathrm{~h}$. IL-6 point-of-care test values above 1,000 pg/mL (positive Il-6 AMC) were found in 12 women (19.4\%) with median interval from PPROM to childbirth $56 \mathrm{~h}$ (min-max: 6.4-288). IL-6 point-of-care test values below 1,000 pg/mL (negative II-6 AMC) were found in 51 women (81.0\%). The neonatal mortality rate was $1.9 \%$ and was associated with prematurity. Conclusion. The major clinical finding of our study is that serial transabdominal amniocentesis with II-6 point-of-care test helps to identify a high inflammatory status in amniotic fluid in women with PPROM. Subsequent expectant management of women with PPROM does not lead to worsening of short-term neonatal outcomes.
\end{abstract}

Key words: PPROM, II-6, poin-of-care test, amniocentesis

Received: February 21, 2020; Revised: August 31, 2020; Accepted: September 15, 2020; Available online: October 1, 2020 https://doi.org/10.5507/bp.2020.041

(c) 2021 The Authors; https://creativecommons.org/licenses/by/4.0/

${ }^{a}$ Department of Obstetrics and Gynecology, Faculty of Medicine and Dentistry, Palacky University Olomouc and University Hospital Olomouc, I. P. Pavlova 6, 77520 Olomouc, Czech Republic

${ }^{b}$ Department of Medical Biophysics, Faculty of Medicine and Dentistry, Palacky University Olomouc, Hnevotinska 3, 77900 Olomouc, Czech Republic

'Department of Neonatology, Faculty of Medicine and Dentistry, Palacky University Olomouc and University Hospital Olomouc, I. P. Pavlova 6, 77520 Olomouc, Czech Republic

Corresponding author: Radovan Pilka, e-mail: radovan.pilka@fnol.cz

\section{INTRODUCTION}

Early leakage of amniotic fluid in a low week of pregnancy (PPROM) is regarded as an aberration of the integrity of the fetal envelope with efflux of the amniotic fluid that precedes the onset of uterine activity. It complicates about $2-4 \%$ (ref. $^{1}$ ) of all births. It is related to the lower gestational age of the fetuses and in consequence results in higher perinatal and maternal morbidity. PPROM can be subdivided according to gestational age into early PPROM (between 24+0 and 33+6 weeks) and late PPROM (between $34+0$ to $36+6$ weeks) (ref. ${ }^{2,3}$ ).

Gestational age is the decisive factor in the management of PPROM cases. An active approach is generally applied above $34+7$ gestational week ${ }^{4}$. Although there are data indicating that this limit should be taken as the 35 th gestational week to increase neonatal benefit, there is no consensus on this matter ${ }^{5}$. The expectant approach is recommended between $24+0$ and $33+7$ weeks $^{3}$. Extension of the latency period nonetheless exposes the fetus to complications such as chorioamnionitis, retroplacental hematoma and fetal distress. Recent data suggest a relationship between placental inflammation and important clinical outcomes such as neurologic impairment and chronic lung disease. This has coincided with a more active clinical approach to the management of chorioamnionitis and preterm labor ${ }^{6}$.

A key role in PPROM etiology is played by an infection in the choriodecidual space and inflammation? Biochemical processes in women with PROM are accompanied by an increase in matrix metalloproteinases (MMP) $\left(\right.$ ref. $\left.^{8}\right)$ in amniotic fluid and a decrease in their inhibitors ${ }^{2,3}$. During premature labor, MMPs stimulate primarily proinflammatory cytokines and prostaglandins. 
These processes lead to violation of fetal membrane integrity, local inflammation, and ascending bacterial colonization with the development of intra-amniotic inflammatory invasion (MIAC) (ref. ${ }^{9}$ ). MIAC complicates PPROM in $20-50 \%$ of cases and depends on gestational age ${ }^{10}$. In amniotic fluid, the most common bacteria are genital mycoplasmas (Ureaplasma urealyticum, Ureaplasma parvum and Mycoplasma hominis). They are found in $70-80 \%$ patients with PPROM ( ref. $^{10}$ ). The presence of bacteria in the amniotic fluid is postulated to activate an intraamniotic innate immune response through the system of pattern recognition receptors, resulting in microbial-associated intraamniotic infection (IAI) ( ref. $^{11}$ ). On the other hand, some endogenous mediators called alarmins (e.g., high mobility group box-1 protein) are released into the amniotic fluid and can trigger development of sterile IAI (the presence of IAI without any proven microorganism in the amniotic fluid) (ref. ${ }^{12}$ ).

U. urealyticum, U. parvum and Mycoplasma hominis are most frequently isolated from the amniotic fluid and placenta in cases of histologic and clinical chorioamnionitis and in association with spontaneous preterm labor (PTL) and PPROM (ref. ${ }^{13}$ ). In addition, HCA is associated with a high concentration of inflammatory mediators in amniotic fluid, including proinflammatory cytokines (TNF- $\alpha$, IL-1 $\beta$, IL-6 and IL-8) (ref. ${ }^{5}$ ) and natural cytokine inhibitors (soluble TNF receptors p55 and p75) (ref..$^{5}$ ). Kacerovsky et al. have shown that the presence of both MIAC and HCA is associated with strong intraamniotic and fetal inflammatory response ${ }^{14}$. Neonates from this subgroup PPROM may be threatened by high risk of infections, such as early onset sepsis, and thus might benefit from an active management including induction of labor. To identify these infection-related and inflammatory intra-amniotic conditions, evaluation of an amniotic fluid sample is considered a gold standard approach ${ }^{15}$. A positive amniotic interleukin (IL)-6 by point-of-care testing was used as the definition of IAI due to its proven prognostic and clinical utility ${ }^{16,17}$. The objective of the current study was to evaluate the role of IL-6 point-of-care test in amniotic fluid obtained from serial amniocentesis in expectantly managed women with PPROM between 24 and 34 weeks of gestation.

\section{METHODS}

We conducted a prospective observational cohort study which included 62 pregnant women with PPROM in gestational week between $22+0$ and $34+0$ who were admitted to the Department of Obstetrics and Gynecology, University Hospital Olomouc, Czechia between May 2015 and September 2018. Women aged >18 years were eligible if they presented with PPROM and a singleton pregnancy. Only women who delivered at $>24.0$ weeks were included in the study. Patients were excluded from the study if they had signs of clinical chorioamnionitis, signs of fetal hypoxia, the presence of either congenital or chromosomal fetal abnormalities, multiple gestation, and cases in which amniocentesis was not possible. Clinical chorioamnionitis was diagnosed in the presence of a maternal temperature of $\geq 37.8^{\circ} \mathrm{C}$ and $\geq 2$ of the following criteria: (1) uterine tenderness; (2) malodorous vaginal discharge; (3) maternal leukocytosis (WBC count of $>15,000$ cells $/ \mathrm{mm}^{3}$ ); (4) maternal tachycardia (>100 beats/ min); and (5) fetal tachycardia ( $>160$ beats/min) (ref. ${ }^{18}$ ).

Enrolled subjects signed informed consent and underwent routine institutional antenatal care for PPROM. This included hospitalization, administration of a course of antenatal steroids (betamethasone acetate/phosphate $12 \mathrm{mg}$ intramuscularly in two doses $24 \mathrm{~h}$ apart) and a standardized course of latency antibiotics (parenteral penicillin). Tocolysis was administered for $48 \mathrm{~h}$ in the absence of clinical chorioamnionitis, abruptio placentae and fetal compromise. Delivery was undertaken for spontaneous preterm labor, nonreassuring maternal or fetal status, clinical concern for infection, or when a gestational age of 34 weeks was reached.

Clinical diagnosis of membrane rupture was based on a history of amniotic fluid leakage, ultrasound assessment of amniotic fluid volume, a sterile speculum examination confirming amniotic fluid drainage from the cervical os, and biochemical tests when in doubt (AmniSure) (ref. ${ }^{19,20}$ ). Clinical chorioamnionitis, placental abruption, umbilical cord prolapse, development of fetal distress and uterine surgery history were taken as the indications for cesarean section.

Upon admission, cervical swabs were obtained for the identification of bacteria. Women with a positive cervical culture were correctly treated parenteraly according to the microorganism isolated. In case of negative finding the antibiotics were withdrawn.

In all women, the maternal blood sampling and a transabdominal amniocentesis were performed at the time of admission prior to the administration of corticosteroids, antibiotics, or tocolytics, to rule out signs of chorioamnionitis. Maternal blood sample was obtained by venipuncture of the cubital vein, and was sent to the laboratory immediately following sampling to assess the levels of inflammatory markers (C-reactive protein and white blood cell count) (ref. $\left.{ }^{21}\right)$.

Routine amniocentesis for patients with PPROM was the preferred management strategy at our perinatal service. Amniotic fluid was collected by sterile transabdominal amniocentesis under ultrasound control and used for the clinical assessment (IL-6 point-of-care test, identification of microorganisms in the amniotic fluid). The remaining fluid was subsequently centrifuged and the supernatant stored at $-80{ }^{\circ} \mathrm{C}$ until analysis. Microbial invasion of amniotic fluid (MIAC) was defined as a positive PCR for genital mycoplasmas and/or a positive amniotic fluid culture ${ }^{22}$. The procedure was deferred in 5 patients with marked oligohydramnios or if the only accessible fluid was found under the central portion of an anterior placenta (Fig. 5). The decision for completing an amniocentesis was at the discretion of the attending perinatologist. In women with amniotic fluid IL-6 pointof-care test $>1000 \mathrm{pg} / \mathrm{mL}$ active management of labor was a standard approach. Patients who did not progress into labor spontaneously, who had no indications for cesarean 
Table 1. Basic characteristics of women with PPROM. The data in the table are presented as the number (\%) or mean / median with (minimum - maximum) values.

\begin{tabular}{|c|c|c|c|c|}
\hline & TOTAL & $\begin{array}{c}\text { IL-6 AMC } \\
\text { positive }\end{array}$ & $\begin{array}{c}\text { IL-6 AMC } \\
\text { negative }\end{array}$ & $P$ \\
\hline Number of patients & 62 & 12 & 50 & - \\
\hline $\begin{array}{l}\text { Age of patients }(y r) \\
\text { mean } \pm \text { SD }(\min -\max )\end{array}$ & $\begin{array}{c}30.9 \pm 5.4 \\
(19-41)\end{array}$ & $\begin{array}{l}29.9 \pm 5.4 \\
(22-39)\end{array}$ & $\begin{array}{c}31.1 \pm 5.5 \\
(19-41)\end{array}$ & 0.406 \\
\hline Smoker & $12(19.4 \%)$ & $4(33.3 \%)$ & $8(16.0 \%)$ & 0.223 \\
\hline Parity & & & & 0.213 \\
\hline 0 & $4(6.5 \%)$ & $1(8.3 \%)$ & $3(6.0 \%)$ & \\
\hline 1 & $34(54.8 \%)$ & $4(33.3 \%)$ & $30(60.0 \%)$ & \\
\hline 2 & $16(25.8 \%)$ & $4(33.3 \%)$ & $12(24.0 \%)$ & \\
\hline 3 & $5(8.1 \%)$ & $2(16.7 \%)$ & $3(6.0 \%)$ & \\
\hline 4 & $0(0 \%)$ & $0(0 \%)$ & $0(0 \%)$ & \\
\hline 5 & $1(1.6 \%)$ & $0(0 \%)$ & $1(2.0 \%)$ & \\
\hline 6 & $1(1.6 \%)$ & $0(0 \%)$ & $1(2.0 \%)$ & \\
\hline 7 & $1(1.6 \%)$ & $1(0 \%)$ & $0(0 \%)$ & \\
\hline $\begin{array}{l}\text { Gestational age at time of PPROM }(w k+d) \\
\text { mean (min-max) }\end{array}$ & $\begin{array}{c}31+0 \\
(22+2-34+0)\end{array}$ & $\begin{array}{c}29+4 \\
(25+1-32+4)\end{array}$ & $\begin{array}{c}31+3 \\
(22+2-34+0)\end{array}$ & 0.009 \\
\hline $\begin{array}{l}\text { Gestational age at time of labor }(w k+d) \\
\text { mean }(\min -\max )\end{array}$ & $\begin{array}{c}32+1 \\
(26+1-35+0)\end{array}$ & $\begin{array}{c}30+1 \\
(26+1-33+1)\end{array}$ & $\begin{array}{c}32+4 \\
(27+2-35+2)\end{array}$ & 0.001 \\
\hline $\begin{array}{l}\text { Latency from PPROM to labor }(\mathrm{h}) \\
\text { median (min-max) }\end{array}$ & $112(4-606)$ & $55.9(6-288)$ & $118.5(4-606)$ & 0.042 \\
\hline $\begin{array}{l}\text { Type of labor } \\
\text { vaginal } \\
\text { Cesarean section }\end{array}$ & $\begin{array}{l}41(66.1 \%) \\
20(32.3 \%)\end{array}$ & $\begin{array}{l}9(75.0 \%) \\
3(25.0 \%)\end{array}$ & $\begin{array}{l}31(64.6 \%) \\
17(35.4 \%)\end{array}$ & 0.773 \\
\hline CRP median (min-max) & $6.2(0.6-84.8)$ & $9.5(0.6-84.8)$ & $5.8(0.6-23.5)$ & 0.012 \\
\hline WBC median (min-max) & $11.9(6.9-24.0)$ & $12.4(7.0-24.0)$ & 11.9. $(6.9-21.5)$ & 0.514 \\
\hline
\end{tabular}

Table 2. Microbes identified in the cervical swabs in women with PPROM.

\begin{tabular}{lcccc}
\hline Microbes & $\begin{array}{c}\text { TOTAL } \\
(\mathrm{n}=62)\end{array}$ & $\begin{array}{c}\text { IL-6 AMC positive } \\
(\mathrm{n}=12)\end{array}$ & $\begin{array}{c}\text { IL-6 AMC negative } \\
(\mathrm{n}=50)\end{array}$ & $P$ \\
\hline Negative finding & $21(33.9 \%)$ & $3(25.0 \%)$ & $18(36.0 \%)$ & 0.735 \\
Ureaplasma spp. & $20(32.3 \%)$ & $5(41.7 \%)$ & $15(30.0 \%)$ & 0.500 \\
Escherichia coli & $10(16.4 \%)$ & $2(16.7 \%)$ & $10(20.0 \%)$ & 1.000 \\
Group B Streptococcus spp. & $7(11.3 \%)$ & $1(8.3 \%)$ & $6(12.0 \%)$ & 1.000 \\
Mycoplasma spp. & $7(11.5 \%)$ & $2(16.7 \%)$ & $5(10.0 \%)$ & 0.612 \\
Enterococcus spp. & $7(11.3 \%)$ & $1(8.3 \%)$ & $6(12.0 \%)$ & 1.000 \\
Klebsiella spp. & $2(3.3 \%)$ & $2(16.7 \%)$ & $0(0 \%)$ & $\mathbf{0 . 0 3 5}$ \\
Pseudomonas & $1(1.6 \%)$ & $0(0 \%)$ & $1(2.0 \%)$ & 1.000 \\
Yeasts & $1(1.6 \%)$ & $0(0 \%)$ & $1(2.0 \%)$ & 1.000 \\
\hline
\end{tabular}

Table 3. Microbes identified in the amniotic fluid from amniocentesis in women with PPROM.

\begin{tabular}{|c|c|c|c|c|}
\hline Microbes & $\begin{array}{l}\text { TOTAL } \\
(n=62)\end{array}$ & $\begin{array}{c}\text { IL-6 AMC positive } \\
(\mathrm{n}=12)\end{array}$ & $\begin{array}{l}\text { IL-6 AMC negative } \\
(\mathrm{n}=50)\end{array}$ & $P$ \\
\hline Negative finding & $48(78.7 \%)$ & $5(41.7 \%)$ & $43(87.8 \%)$ & 0.002 \\
\hline Ureaplasma spp. & $10(16.1 \%)$ & $6(50.0 \%)$ & $4(8.2 \%)$ & 0.002 \\
\hline Group B Streptococcus spp. & $1(1.6 \%)$ & $1(8.3 \%)$ & $0(0 \%)$ & 0.197 \\
\hline Peptostreptococcus & $1(1.6 \%)$ & $0(0 \%)$ & $1(2.0 \%)$ & 1.000 \\
\hline Lactobacillus & $1(1.6 \%)$ & $0(0 \%)$ & $1(2.0 \%)$ & 1.000 \\
\hline Klebsiella spp. & $1(1.6 \%)$ & $0(0 \%)$ & $1(2.0 \%)$ & 1.000 \\
\hline Citrobacter & $1(1.6 \%)$ & $0(0 \%)$ & $1(2.0 \%)$ & 1.000 \\
\hline Mycoplasma & $1(1.6 \%)$ & $1(8.3 \%)$ & $0(0 \%)$ & 0.197 \\
\hline Haemophilus & $1(1.6 \%)$ & $0(0 \%)$ & $1(2.0 \%)$ & 1.000 \\
\hline
\end{tabular}


section, with no signs of clinical chorioamnionitis, with amniotic fluid IL-6 point-of-care test $<1000 \mathrm{pg} / \mathrm{mL}$ and without increase in maternal CRP and white blood cell count, were followed up. In a subgroup of patients with gestational age below 26 weeks a conservative clinical management prevailed even in cases with positive Il-6 point-of-care test ${ }^{1}$.

Maternal temperature, maternal serum C-reactive protein (CRP) and white blood cell (WBC) counts were assayed every subsequent day until delivery. After one week of expectant management of PPROM, second amniocentesis with amniotic fluid sampling was performed in 10 patients who did not deliver. In patients with amniotic fluid IL-6 point-of-care test $>1000 \mathrm{pg} / \mathrm{mL}$ an active management of labor was adopted. Subgroup of patients with IL-6 point-of-care test $<1000 \mathrm{pg} / \mathrm{mL}$ continued with expectant management of PPROM.

Analysis of amniotic fluid samples for IL-6 concentrations

Amniotic fluid was used for the clinical assessment (IL-6 point-of-care test, identification of microorganisms in the amniotic fluid. For the automated electrochemiluminiscence immunoassay method, the amniotic fluid IL-6 concentrations $(\mathrm{pg} / \mathrm{mL})$ were measured using the immuno-analyzer Milenia POCScan (Milenia Biotec, Giesen, Germany) (ref. ${ }^{23}$ ). For each patient, $0.1 \mathrm{ml}$ of amniotic fluid was pipetted to the sampling well of the Picoscan cassette. The IL- 6 cassette is a lateral flow immunoassay that requires $20 \mathrm{~min}$ incubation at room temperature. The Picoscan analyzer measures the color intensity of the test band and calculates the IL- 6 concentration $(\mathrm{pg} / \mathrm{mL})$ according to a stored standard curve.

\section{Detection of Ureaplasma species and Mycoplasma homi- nis in the amniotic fluid}

DNA was isolated from the amniotic fluid using the QIAamp DNA mini kit (Qiagen, Hilden, Germany) according to the manufacturer's instructions (using the protocol for isolating bacterial DNA from biological fluids). RT-PCR was performed using the Rotor-Gene 6000 instrument (Qiagen, Hilden, Germany) employing the commercial AmpliSens ${ }^{\circledR}$ C. Ureaplasma/M. hominis-FRT kit (Federal State Institution of Science, Central Research Institute of Epidemiology, Moscow, Russia) to detect DNA from Ureaplasma species and Mycoplasma species in a common PCR tube. As a control, we included a PCR run for beta-actin, a housekeeping gene, to exclude the presence of PCR inhibitors ${ }^{24}$.

For all newborns, medical records regarding neonatal morbidity and mortality were reviewed. Short-term neonatal outcome included the presence of the following outcomes: the incidence of early-onset sepsis (EOS) and late-onset sepsis (LOS). Definitive cases of sepsis were those infants with positive blood cultures. The sepsis cases in the first 7 days were defined as early sepsis, and sepsis cases after the seventh day were accepted as late sepsis ${ }^{25}$.

In 56 cases, the placenta was sent for histological examination after delivery. Acute chorioamnionitis was diagnosed based on the degree of polymorphonuclear leukocyte infiltration that was inspected separately in the free membranes (amnion and choriondecidua), chorionic plate and umbilical cord, according to criteria proposed by Salafia et al. ${ }^{26,27}$. Chronic choriomnionitis was defined by the infiltration of the organ by lymphocytes, plasma cells and/or macrophages ${ }^{28}$. This study was approved by the Institutional Review Board Committee. Statistical analysis of the results was carried out using the IBM SPSS Statistics version 22. The normality of data was tested using Shapiro-Wilk test. To analyse correlation between maternal CRP and IL-6 point-of-care test Spearman's correlation analysis was used. The Fisher' sexact test was used to compare I1-6 AMC positive and negative groups in categorical parameters. The Student's test or MannWhitney U-test were used to compare the differences between groups for quantitative variables. Tests were performed at a $5 \%$ level of significance.

\section{RESULTS}

In total, 62 women aged 19 to 41 years were recruited in the study. The mean age of women was 30.9 years. The mean gestational age at the time of PPROM was $31+0$, median $31+6$, minimum $22+2$ and maximum $34+0$ (Table 1, Fig. 1). The mean gestational age at labor was $32+1$, median $32+4$, minimum $26+1$ and maximum $35+0$. The median time from PPROM to childbirth was $112 \mathrm{~h}$ (4.7 days), minimum latency length was $4 \mathrm{~h}$ and maximum $606 \mathrm{~h}$ (25.3 days). Maternal CRP values ranged from 0.6 to $84.8 \mathrm{mg} / \mathrm{L}$ with a median of $6.2 \mathrm{mg} / \mathrm{L}$. In 31 women (49.2\%) the maternal CRP value was above $6 \mathrm{mg} / \mathrm{L}$. To evaluate correlation between maternal CRP, and IL-6 point-of-care test Spearman's correlation analysis was applied. This showed a significant positive correlation between maternal CRP and IL-6 point-of-care test $(\mathrm{r}=0.364$; $P=0.006$ ) (Fig. 4).

The majority of patients $41(66.1 \%)$ delivered vaginally, caesarean section was performed in 20 (32.3\%) women (Table 1). Negative microbial finding was found $21(33.9 \%)$ and $48(77.4 \%)$ of cervical swabs and amniotic fluid samples respectively. Ureaplasma spp. was the most common microbial finding present in 20 (32.3\%) cervical swabs and in 10 (16.1\%) amniotic fluid samples (Table 2 and 3 ). The median of antibiotic treatment interval was 3 days (min-max: 1-9). In all women, antibiotic therapy has been initiated parenteraly with Penicillin G (PNC) as latency treatment which was subsequently modified according to the results of microbial cultures. In 18 cases (28.6\%) macrolide antibiotics were administered. PNC alone or in combination with Clarithromycin was administered in $44(71.0 \%)$, and $11(17.7 \%)$ patients respectively (Table 4). Signs of acute or chronic chorioamnionitis were found in $16(25.8 \%)$ and $3(4.8 \%)$ patients respectively (Table 5).

The median IL-6 point-of-care (Il-6 AMC) test values from amniocentesis was $264 \mathrm{pg} / \mathrm{mL}$ (min-max: 50-10,000) (Fig. 3). IL-6 point-of-care test values above $1,000 \mathrm{pg} / \mathrm{mL}$ (positive Il-6 AMC) were found in 12 women (19.4\%). The mean age of women was 29.9 years (min-max: 22-39). The mean gestational age at PPROM was $29+4$, median 


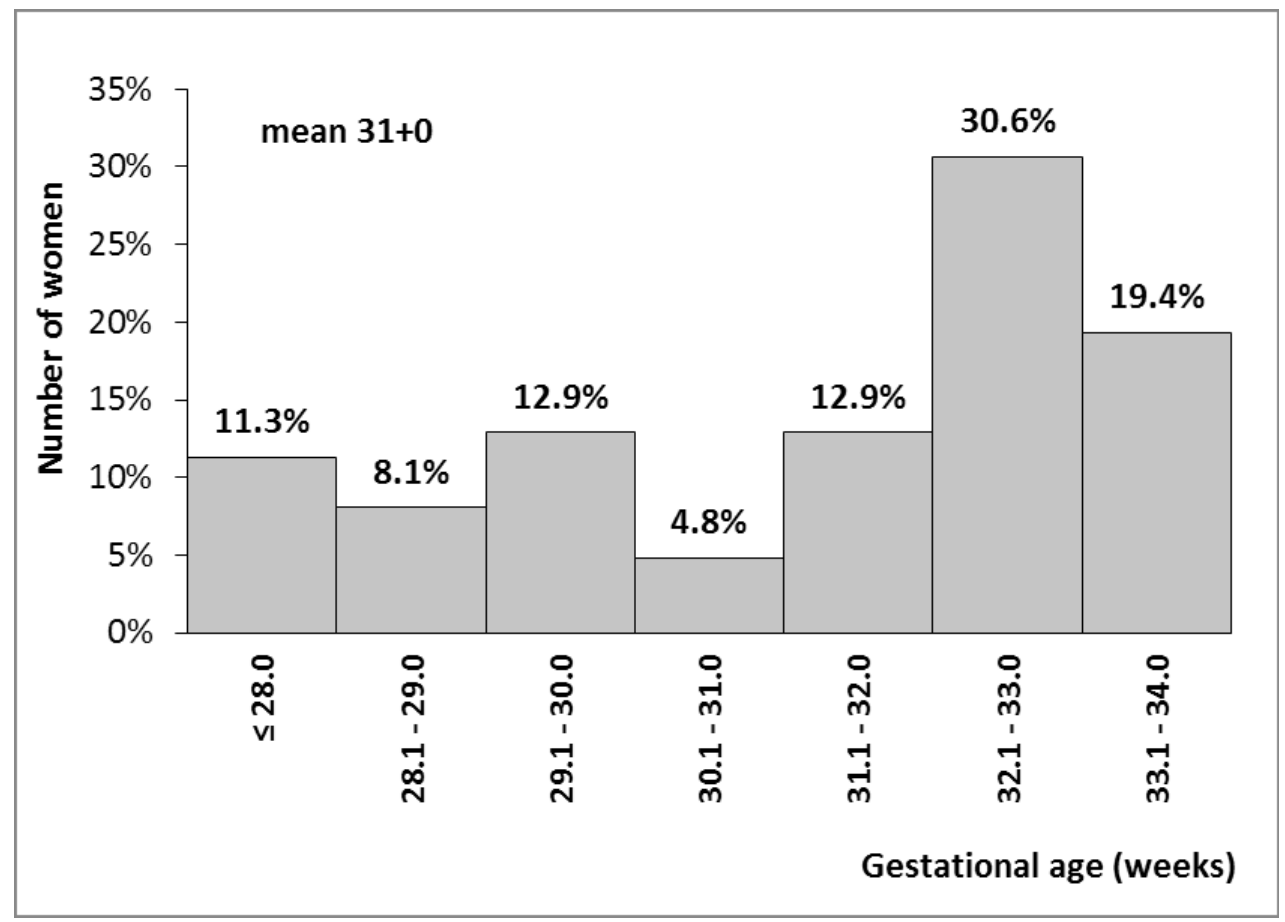

Fig. 1. Distribution of women according to gestational age at PPROM.

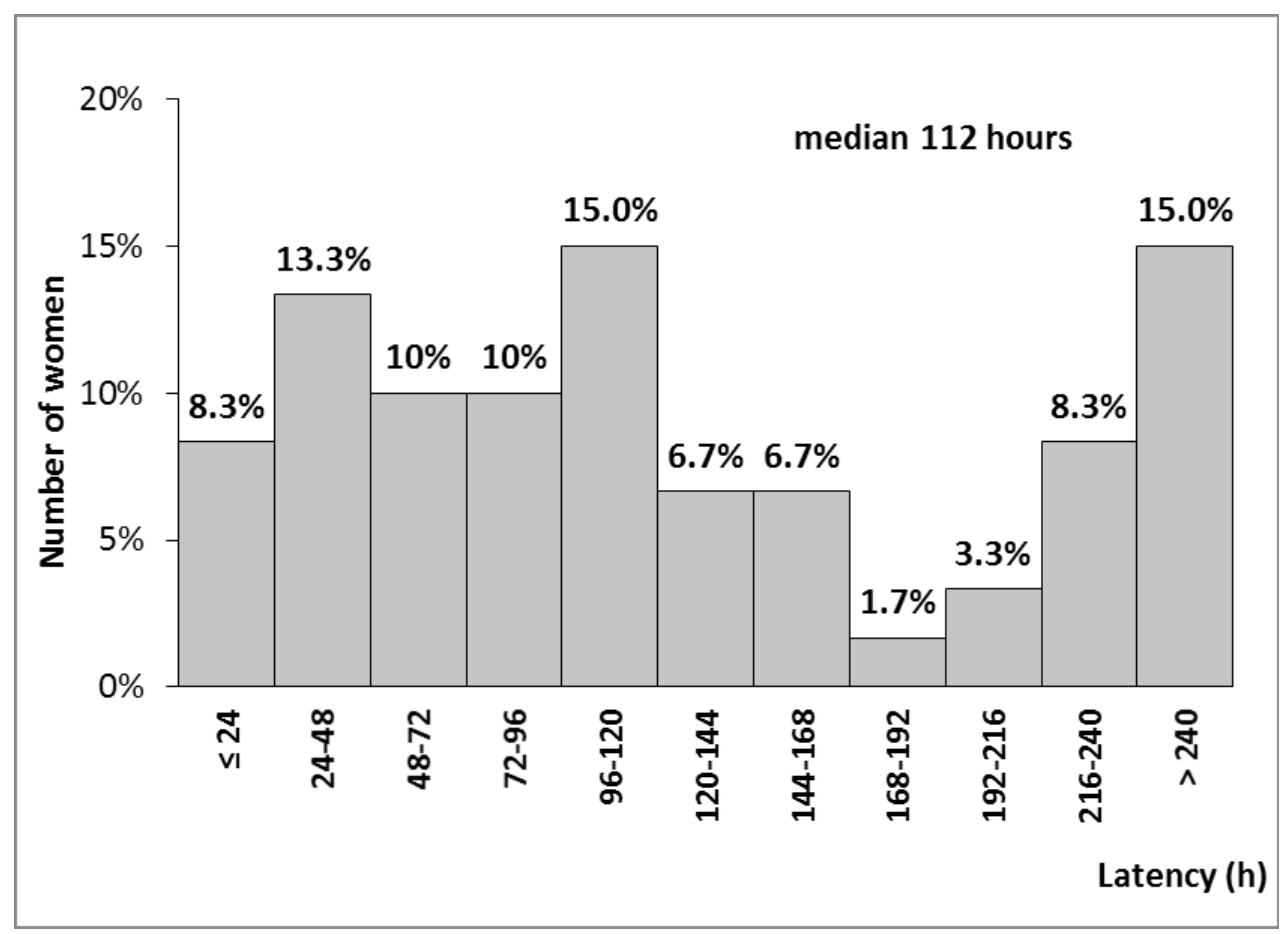

Fig. 2. Distribution of latency time from PPROM to labor.

$29+5$, minimum $25+1$ and maximum $32+4$. The mean gestational age at birth was $30+1$, median $29+6$, minimum $26+1$ and maximum $33+1$. Median interval from PPROM to childbirth was $56 \mathrm{~h}$ (min-max: 6.4-288) (Table 1). IL-6 point-of-care test values below $1,000 \mathrm{pg} / \mathrm{mL}$ (negative Il-6 AMC) were found in 50 women (80.6\%). Lower gestational age at time of PPROM $(P=0.009)$, lower gestational age at time of labor $(P=0.001)$ and shorter latency period from PPROM to labor $(P=0.042)$ were shown in women with positive I1-6 AMC. Maternal CRP values in women with IL-6 point-of-care test value $>1,000 \mathrm{pg} / \mathrm{mL}$ ranged from 0.6 to $85 \mathrm{mg} / \mathrm{L}$ with a median of $9.5 \mathrm{mg} / \mathrm{L}$. In 10 women (83.3\%), the maternal CRP was above $6 \mathrm{mg} / \mathrm{L}$. Levels of maternal CRP were lower (median 5.8; range 0.6 - 23.5) in Il-6 AMC negative subgroup $(P=0.012)$, while white blood cell counts were not different between both groups (Table 1). In cervical culture, the presence of Klebsiella spp. was found to be high in women with positive IL-6 


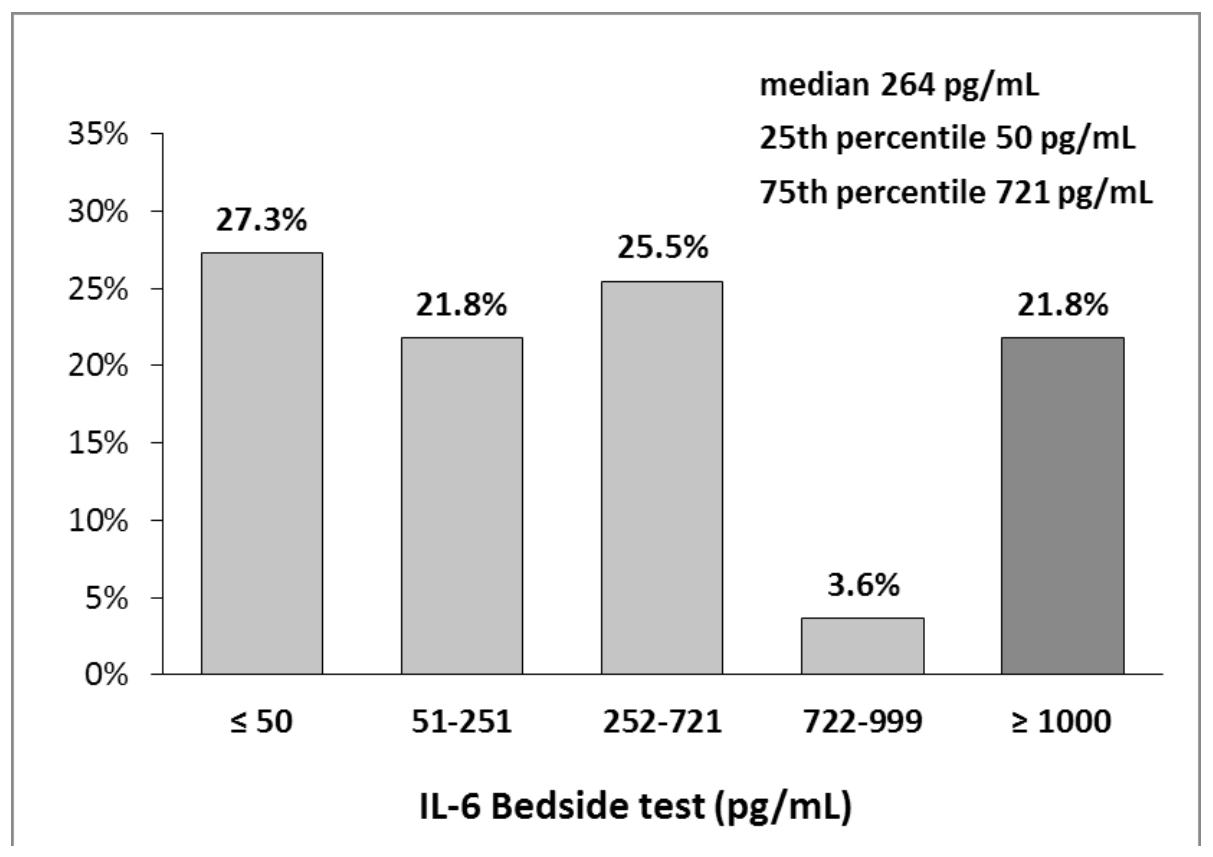

Fig. 3. Distribution of IL-6 point-of-care test values in women with PPROM.

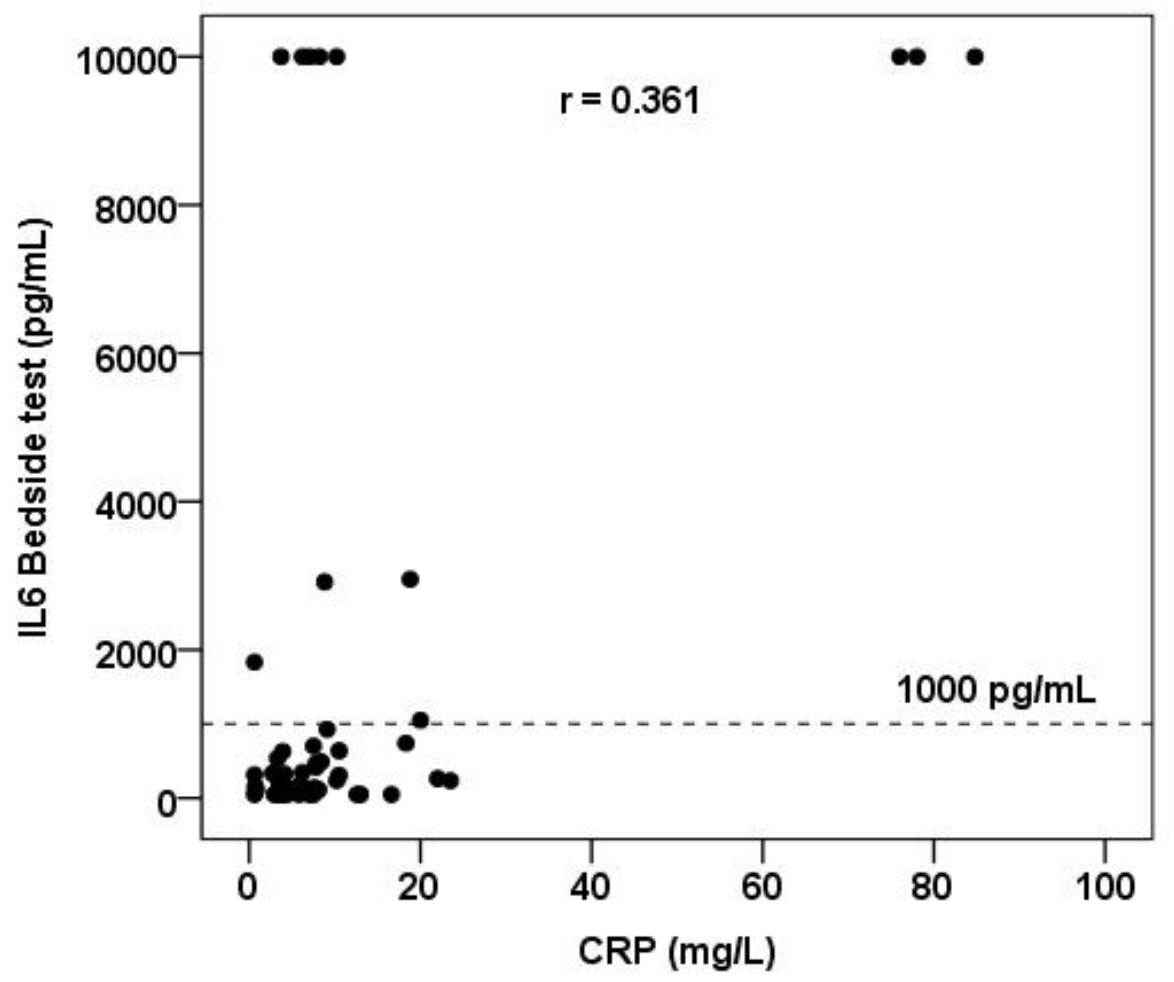

Fig. 4. Correlation between maternal CRP and IL-6 point-of-care test in women with PPROM.

AMC (16.7\%) while negative $(0 \%)$ in patients with IL-6 point-of-care test below $1,000 \mathrm{pg} / \mathrm{mL}, P=0.035$. In amniotic fluid, the presence of Ureplasma spp. was higher in patients with positive Il-6 AMC (50.0\%) when compared to women with negative Il-6 AMC ( $8.2 \%), P=0.002$. The presence of other microbes was not significantly different between groups (Table 3). Age, smoking, parity and type of labor were no different between groups of women with negative or positive Il-6 AMC (Table 1, Fig. 2). Acute cho- rioamnionitis was found more often in women with positive Il-6 AMC as compared with subgroup of women with negative Il-6 AMC (66.8\% vs. $16.0 \%), P=0.011$. Chronic chorioamnionitis or no signs of placental inflammation were found more frequently in women with negative IL-6 $\operatorname{AMC}(P=0.011)$ (Table 5).

Early-onset neonatal sepsis was diagnosed in 8 neonates (12.7\%) (Fig. 5). In 4 out of 8 neonates placental signs of acute chorioamnionitis were shown, in 3 cases 
Table 4. Antibiotic treatment in women with PPROM.

\begin{tabular}{|c|c|c|c|c|}
\hline Antibiotics & & $\begin{array}{l}\text { IL-6 AMC positive } \\
(\mathrm{n}=12)\end{array}$ & $\begin{array}{l}\text { IL-6 AMC negative } \\
(\mathrm{n}=50)\end{array}$ & $P$ \\
\hline PNC & $44(71.0 \%)$ & $7(58.3 \%)$ & $37(74.0 \%)$ & 0.305 \\
\hline PNC + Clarithromycin & $11(17.7 \%)$ & $2(16.7 \%)$ & $9(18.0 \%)$ & 1.000 \\
\hline PNC + Azithromycin & $2(3.2 \%)$ & $0(0 \%)$ & $2(4.0 \%)$ & 1.000 \\
\hline Clindamycin & $2(3.2 \%)$ & $2(16.7 \%)$ & $0(0 \%)$ & 0.035 \\
\hline Clarithromycin & $1(1.6 \%)$ & $0(0 \%)$ & $1(2.0 \%)$ & 1.000 \\
\hline Ampicillin and Sulbactam + Azithromycin & $1(1.6 \%)$ & $0(0 \%)$ & $1(2.0 \%)$ & 1.000 \\
\hline Amoxicillin + Clavulanic Acid + Azithromycin & $1(1.6 \%)$ & $1(8.3 \%)$ & $0(0 \%)$ & 0.194 \\
\hline
\end{tabular}

Table 5. Placental histopathology in women with PPROM.

\begin{tabular}{lcccc}
\hline Histological finding & $\begin{array}{c}\text { TOTAL } \\
(\mathrm{n}=62)\end{array}$ & $\begin{array}{c}\text { IL-6 AMC positive } \\
(\mathrm{n}=12)\end{array}$ & $\begin{array}{c}\text { IL-6 AMC negative } \\
(\mathrm{n}=50)\end{array}$ & $P$ \\
\hline Acute inflammation & $16(25.8 \%)$ & $8(66.8 \%)$ & $8(16.0 \%)$ & $\mathbf{0 . 0 1 1}$ \\
$\quad$ purulent inflammation & $7(11.3 \%)$ & $2(16.6 \%)$ & $5(10.0 \%)$ & 0.614 \\
\hline Chronic inflammation & $3(4.8 \%)$ & $1(8.3 \%)$ & $2(4.0 \%)$ & 1.000 \\
\hline Without inflammation & $26(41.9 \%)$ & $1(8.3 \%)$ & $35(70.0 \%)$ & $\mathbf{0 . 0 1 1}$ \\
\hline
\end{tabular}

placental histopathology was negative. In 1 case, placental histology was not performed. This patient was shown as Il-6 AMC negative, with negative microbial finding from amniotic fluid and maternal CRP at the level $8.1 \mathrm{mg} / \mathrm{L}$. She delivered at $34+3$ weeks with positive microbial finding in the cervical culture (E.colli, Pseudomonas aeruginosae) In one out of 8 cases (from the Il-6 AMC positive subgroup) the newborn after six days of latency died ( 7 days after delivery; $26+1,700 \mathrm{~g}$ ) due to prematurity (respiratory distress syndrome). In this case the placenta had signs of purulent acute chorioamnionitis. Late neonatal sepsis was observed in 2 newborns (3.2\%) (Fig. 5). In one case a woman in the Il-6 AMC positive subgroup delivered at $26+1(850 \mathrm{~g})$ weeks, in the second case a woman in the Il-6 AMC negative subgroup delivered at 27+2 (1025 g) weeks. In both cases, the placental histology was negative.

\section{DISCUSSION}

To reduce maternal and neonatal infections and gestational-age-dependent morbidity in expectant management, a 7-day course of therapy with a combination of intravenous ampicillin and erythromycin followed by oral amoxicillin and erythromycin is recommended for women with preterm PROM who are less than $34+0$ weeks of gestation ${ }^{4,1}$. however, there are no clear recommendations on how often and using which parameters expectant management should be performed. In this prospective study we incorporated repeated transabdominal amniocentesis into expectant management of women with PPROM to be able more precisely evaluate the risk of MIAC and subsequent HCA. The assessment of Il-6 from amniotic fluid is one of the most common approaches in evaluating the systemic inflammatory response and its intensity in women with PPROM.

\section{Intraamniotic Il-6}

In our study we identified 12 (19.4\%) (Table 1) cases of PPROM as Il-6 positive, using cut-off value of $>1,000$ $\mathrm{pg} / \mathrm{mL}$. The cut-off values of the amniotic fluid IL- 6 concentration to identify IAI in women with PPROM have been developed for the past years. In 1993, Romero et al. established the amniotic fluid IL-6 concentration cut-off value of $7.9 \mathrm{ng} / \mathrm{mL}$ in women with PPROM with a sensitivity of $81 \%$, specificity of $75 \%$, positive predictive value of $67 \%$, and negative predictive value of $86 \%$ (ref. $^{29}$ ). In 2014 Kacerovsky et al. established the amniotic fluid IL-6 poin-of-care test cut-off value of $1000 \mathrm{pg} / \mathrm{mL}$ in women with PPROM with a sensitivity of $60 \%$, specificity of $94 \%$, positive predictive value of $75 \%$, and negative predictive value of $88 \%$ to be optimal for prediction of both MIAC and HCA ( ref. $^{21}$ ). Musilova et al. using the same pointof-care detection system as our group observed presence of microbial-associated IAI (both IAI and MIAC) in $21 \%$ (34/166) of women. If the diagnosis of IAI was expanded to include both a positive IL-6 and neutrophil infiltration of the amnion (histological amnionitis), then the proportion of women with IAI was $23 \%$ (ref. ${ }^{30}$ ). These data correlate with our results, although a slightly higher proportion of IAI in the study group of Musilova et al. could be explained by their lower cut-off level for I1-6 (745 $\mathrm{pg} / \mathrm{mL})$.

\section{Maternal CRP}

In a subgroup of patients with positive Il-6 AMC test we have found higher levels of maternal CRP as compared to Il-6 AMC test negative woment. Maternal serum CRP has been proposed as a marker of infection and inflammation in several diseases ${ }^{31}$. With MIAC and HCA, CRP exhibited a weak and contradictory association. A systematic review by Martinez et al. concluded that there was no evidence to support the use of CRP as a tool for the 


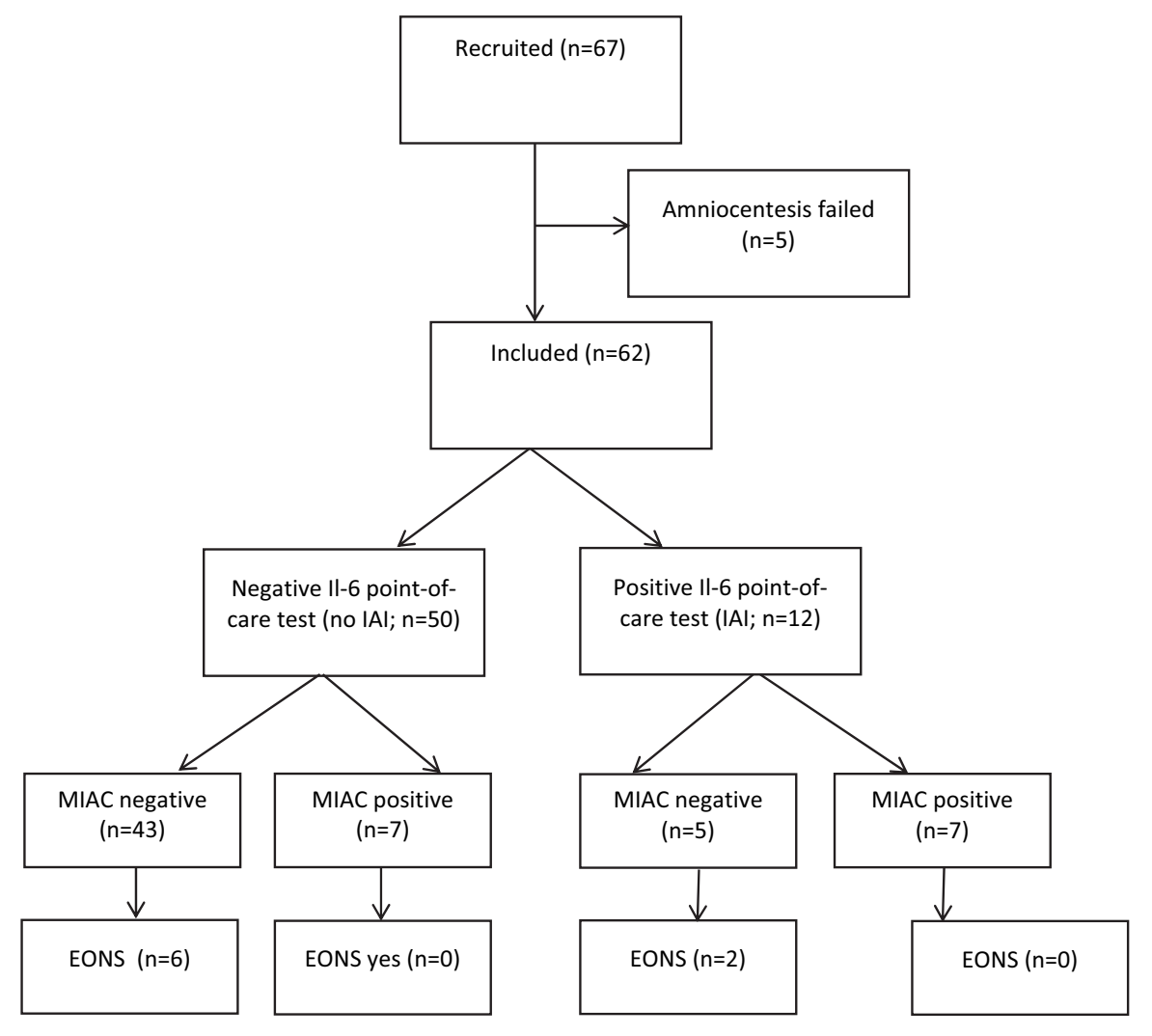

Fig. 5. Flowchart of the study.

prediction of HCA and significant differences were reported when CRP levels were compared between PPROM women with or without MIAC (ref. ${ }^{32,33}$ ). Stepan et al. in their large study found out that only the extreme cut-off levels of CRP, represented by the 95th percentile, predicted the presence of MIAC and HCA below 32 weeks of gestation. However, the low sensitivity limits the clinical utility of this detection method ${ }^{34}$. Also, in our data we found very low correlation between Il-6 poin-of-care test and levels of maternal CRP (Fig. 4).

\section{White blood cell counts}

There was no difference in white blood cell counts between the Il-6 AMC positive and negative subgroups in our study. Different maternal WBC count cutoff values have been proposed to predict MIAC, histological or clinical chorioamnionitis, and neonatal infection ${ }^{35,36}$. However, none of these values have good predictive indices. Musilova et al. showed a maternal WBC count cutoff value $14.0 \times 109 / \mathrm{L}$ to have a good negative predictive value, but its positive predictive value and likelihood ratio were poor. Our data are consistent with their conclusion that this prevents WBC count cutoff value from being used in the clinical setting ${ }^{20}$.

\section{Microbial findings in cervical cultures}

Ureaplasma spp. was detected in cervical cultures of $20(32.3 \%)$ and in amniotic fluid samples of $10(16.1 \%)$ patients and was the most common microbial pathogen in our study group (Table 2). Ureaplasma spp. are considered a part of normal genital flora and have an average colonisation rate of $40-80 \%$ (ref. ${ }^{37}$ ). In their study, Gupta et al. determined the presence of

Ureaplasma urealyticum in the lower genital tract of $32 \%$ of infertile women ${ }^{38}$ However, according to recently published data, U. urealyticum, U. parvum and Mycoplasma hominis are most frequently isolated from the amniotic fluid and placenta in cases of histologic and clinical chorioamnionitis and in association with spontaneous PTL and PROM (ref. ${ }^{39,40}$ ). Kacerovsky et al. found Ureaplasma spp. in 21\% of women with PPROM (ref. ${ }^{21}$ ). More recently, Pavlidis et al. used a mouse model to show ascending infection of Ureaplasma parvum is associated with preterm birth. The study reports an increase in preterm birth from $13 \%$ to $28 \%$ following vaginal colonisation with Ureaplasma and upregulation of pro-inflammatory cytokines, aligning with the human clinical response ${ }^{41}$. Thus, our data are in accordance with recent literature showing Ureaplasma spp. as one of the most common microbes in female genital tract, and associated with adverse pregnancy outcomes such as preterm birth, stillbirth, histologic chorioamnionitis, and neonatal morbidities.

\section{Antibiotic treatment}

The most common antibiotic regimen used in our study was parenteral PNC alone administered in 71.0\% of patients, followed by combination of PNC with Clarithromycin which was administered in $17.7 \%$ of cases (Table 4). The practice of administering antibiotics to patients with preterm PROM is grounded in the results of multiple randomized clinical trials and a large systematic review and meta-analysis ${ }^{42-44}$. Antimicrobial 
agents have been shown to prolong the latency period, decrease neonatal infection, and reduce respiratory morbidity $^{44,45}$. Several antibiotic regimens have been used in patients with preterm PROM, including ampicillin, amoxicillin-clavulanate, penicillin, erythromycin, mezlocillin, pipericillin, cefexin, cefizox, gentamicin, clindamycin, azithromycin and combinations of different agents ${ }^{44}$. The current recommendation in Czechia includes intravenous PNC G (ref. ${ }^{22}$ ). However, penicillin is not effective in the treatment of PPROM (ref. ${ }^{44}$ ). Therefore we adopted parenteral antibiotic treatment according to the microorganism isolated from the amniotic fluid. Gomez et al. followed 46 patients with preterm PROM for whom amniocenteses were performed between 18-32 weeks. In their study the prevalence of intra-amniotic inflammation for the initial amniocentesis was $39 \%$, seven patients had a positive amniotic fluid culture for bacteria $\left(\right.$ ref. $\left.^{46}\right)$. Nevertheless, at the time of the follow-up amniocentesis, six of these seven patients still had a positive amniotic fluid culture despite having received antibiotics ${ }^{46}$. The authors hypothesized that although the overall effect of antibiotic administration in patients with preterm PROM is beneficial in the short term, there is a subset of fetuses who will be exposed to a chronic intrauterine inflammatory process.

\section{Serial intraamniotic inflammation}

In our study we observed no patients with positive amniotic fluid microbial cultivation undergoing serial amniocentesis. However, in three out of these ten cases the Il-6 AMC test was positive. Intensity of intra-amniotic inflammatory response increases gradually when innate imunity defense is activated by the presence of bacteria in either the amniotic fluid or the fetal membranes. However, it has been suggested that intra-amniotic inflammation is elicited not only by the activation of pattern recognition receptors recognizing specific

motifs on the surface of bacteria called pathogen-associated molecular pattern (PAMS) but also by endogenous molecules that signal tissue and cellular damage called "alarmins" 47,48 .

Activated immunocompetent cells produce a broad spectrum of inflammatory mediators and chemokines responsible for attraction and migration of neutrophils, macrophages, and other imine cells to the placenta and fetal membranes ${ }^{49}$. This could possibly explain elevated Il-6 AMC levels in our patients with negative microbial results in amniotic fluid samples from serial amniocentesis.

\section{Chorioamnionitis and early-onset neonatal sepsis}

Histological chorioamnionitis complicates almost half of all PPROM cases that occur prior to 34 weeks' gestation $^{50}$. In our study, $26(41.9 \%)$ (Table 5 ) out of 62 women were diagnosed with histopathological sign sof chorioamnionitis which correlates with published data. Maternal chorio-amnionitis after PPROM is associated with higher risks of early-onset neonatal sepsis (EONS) (10.0\% vs. 2.8\%; aOR 3.102; 95\% CI 2.306-4.173; $P<$ 0.001 ) (ref. $\left.{ }^{51}\right)$. We found placental signs of acute chorioamnionitis in $4(6.3 \%)$ out of 8 cases of neonates diag- nosed with early-onset neonatal sepsis (Table 5). Walker et al. found that only $33 \%$ of infants remained undelivered after one week following a PPROM history (ref. ${ }^{52}$ ). In this report, infants with a longer latency were more likely to die compared with age-matched controls. However, Test et al. found no correlation between prolonged latency periods (more than $72 \mathrm{~h}$ ) and increased neonatal mortality rate $^{53}$. In our study, latency period ranged from 4 to 606 hours and the neonatal mortality was found to be $1.6 \%$ due to prematurity (Fig. 2). Fetal losses tend to occur at earlier gestational ages following PPROM. In one series of PPROM cases, all deaths occurred at less than 30 weeks. The intrauterine fetal death rate (FDIU) was reported as $0.9 \%$ while the neonatal mortality rate was reported as $5 \%$ (ref. ${ }^{54}$ ). Baser et al., found the FDIU rate to be $1.5 \%$. All cases were at less than 29 weeks. The neonatal mortality rate was $1.9 \%$ and was associated with prematurity ${ }^{55}$. Some studies have found that chorioamnionitis was associated with neonatal sepsis, however, the present study did not found any association ${ }^{56,57}$.

\section{CONCLUSION}

In conclusion, the major clinical finding of our study is that serial transabdominal amniocentesis with Il-6 pointof-care test helps to identify a high inflammatory status in amniotic fluid in women with PPROM. This seems to be a decisive factor for determination between active and expectant management of women with PPROM. Prolonged latency period with expectant management did not lead to increased neonatal mortality rate. Further studies are required to determine whether long-term neonatal outcomes differ according to the specific inflammatory response.

\section{ABBREVIATIONS}

GBS Group B streptococcus; HCA, histological chorioamnionitis; IL-1 $\beta$, IL-6, IL-8 Interleukin 1 $\beta$, 6, 8; MIAC, microbial invasion into the amniotic cavity; PPROM, preterm premature rupture of membranes; PNC, penicillin; sRAGE, soluble receptor for advanced glycation end products; TLR Toll-like receptor; TNF- $\alpha$, tumour necrosis factor $\alpha$.

Acknowledgement: Supported by MH CR - DRO (FNO1, 00098892).

Author contributions: VF: manuscript writing, conceived and designed the analysis, contributed data and analysis tools; EH, KH, MS, JH: data collection; JZ: performed the analysis; RP: manuscript writing, conceived and designed the analysis.

Conflict of interest statement: The authors state that there are no conflicts of interest regarding the publication of this article. 


\section{REFERENCES}

1. Kacerovský $M$, Koucký $M$, Křepelka P, Lamberská $T$, Mašata J, Měchurová A, Pařízek A, Smíšek J, Šimják P, Velebil P. Předčasný odtok plodové vody před termínem porodu. Doporučený postup. Ceska Gynekol 2017;82(2):166-7. (In Czech)

2. Kacerovsky M, Drahosova M, Hornychova $H$, Pliskova L, Bolehovska R, Forstl M, Tosner J, Lesko D, Andrys C. Amniotic fluid interleukin 6 levels in preterm premature rupture of membranes. Ceska Gyneko 2009;74(6):403-10. (In Czech)

3. Kacerovsky M, Musilova I. Management of preterm prelabor rupture of membranes with respect to the inflammatory complications - our experiences. Ceska Gynekol 2013;78(6):509-13. (In Czech)

4. Kuba K, Bernstein PS. ACOG Practice Bulletin No. 188: Prelabor Rupture of Membranes. Obstet Gynecol 2018;131(6):1163-64. doi:10.1097/AOG.0000000000002663

5. Pettit KE, Caballero A, Wakefield BW, Dudley DJ, Ferguson JE 2nd, Boyle A, Chisholm CA. Targeted delivery at 34 versus 35 weeks in women with preterm prelabor rupture of membranes. J Matern Fetal Neonatal Med 2019;32(20):3331-35. doi: 10.1080/14767058.2018.1463365.

6. Kim CJ, Romero R, Chaemsaithong P, Chaiyasit N, Yoon BH, Kim YM. Acute chorioamnionitis and funisitis: definition, pathologic features, and clinical significance. Am J Obstet Gynecol 2015;213(4 Suppl):S29-52. doi: 10.1016/j.ajog.2015.08.040.

7. Kacerovsky M, Tosner J, Andrys C, Drahosova M, Pliskova L, Forstl $\mathrm{M}$, Hornychova $\mathrm{H}$. [Amniotic fluid heat shock protein 70 concentration in preterm premature rupture of membranes]. Ceska Gynekol 2009;74(2):85-91.

8. Kacerovsky M, Pliskova L, Bolehovska R, Skogstrand K, Hougaard DM Tsiartas $\mathrm{P}$, Jacobsson $\mathrm{B}$. The impact of the microbial load of genital mycoplasmas and gestational age on the intensity of intraamniotic inflammation. Am J Obstet Gynecol 2012;206(4):342 e1-8. doi: 10.1016/j.ajog.2012.01.004

9. Dollner H, Vatten L, Halgunset J, Rahimipoor S, Austgulen R Histologic chorioamnionitis and umbilical serum levels of pro-inflammatory cytokines and cytokine inhibitors. BJOG 2002;109(5):534-9.

10. Kacerovsky M, Celec P, Vlkova B, Skogstrand K, Hougaard DM, Cobo T, Jacobsson B. Amniotic fluid protein profiles of intraamniotic inflammatory response to Ureaplasma spp. and other bacteria. PLoS One 2013;8(3):e60399. doi: 10.1371/journal.pone.0060399

11. Kacerovsky M, Musilova I, Khatibi A, Skogstrand K, Hougaard DM, Tambor V, Tosner J, Jacobsson B. Intraamniotic inflammatory response to bacteria: analysis of multiple amniotic fluid proteins in women with preterm prelabor rupture of membranes. J Matern Fetal Neonatal Med 2012;25(10):2014-9. doi: 10.3109/14767058.2012.671873

12. Bredeson S, Papaconstantinou J, Deford JH, Kechichian T, Syed TA, Saade GR, Menon R. HMGB1 promotes a p38MAPK associated non-infectious inflammatory response pathway in human fetal membranes. PLoS One 2014;9(12):e113799. doi: 10.1371/journal. pone.0113799

13. Sprong KE, Mabenge M, Wright CA, Govender S. Ureaplasma species and preterm birth: current perspectives. Crit Rev Microbiol 2020:113. doi: 10.1080/1040841X.2020.1736986

14. Kacerovsky M, Cobo T, Andrys C, Musilova I, Drahosova M Hornychova $\mathrm{H}$, Janku $\mathrm{P}$, Jacobsson $\mathrm{B}$. The fetal inflammatory response in subgroups of women with preterm prelabor rupture of the membranes. J Matern Fetal Neonatal Med 2013;26(8):795-801. doi: 10.3109/14767058.2013.765404

15. Kacerovsky M, Vlkova B, Musilova I, Andrys C, Pliskova L, Zemlickova $H$, Stranik J, Halada P, Jacobsson B, Celec P. Amniotic fluid cell-free DNA in preterm prelabor rupture of membranes. Prenat Diagn 2018;38(13):1086-95. doi: 10.1002/pd.5366

16. Chaemsaithong $P$, Romero R, Korzeniewski SJ, Martinez-Varea A, Dong Z, Yoon BH, Hassan SS, Chaiworapongsa T,Yeo L. A point of care test for interleukin- 6 in amniotic fluid in preterm prelabor rupture of membranes: a step toward the early treatment of acute intra-amniotic inflammation/infection. J Matern Fetal Neonatal Med 2016;29(3):360-7. doi: 10.3109/14767058.2015.1006621

17. Romero $\mathrm{R}$, Yoon BH, Kenney JS, Gomez R, Allison AC, Sehgal PB. Amniotic fluid interleukin- 6 determinations are of diagnostic and prognostic value in preterm labor. Am J Reprod Immunol 1993;30(23):167-83. doi: 10.1111/j.1600-0897.1993.tb00618.x

18. Romero R, Miranda J, Kusanovic JP, Chaiworapongsa $T$, Chaemsaithong P, Martinez A, Gotsch F, Dong Z, Ahmed Al, Shaman M, Lannaman K, Yoon BH, Hassan SS, Kim CJ, Korzeniewski SJ, Yeo L, Kim YM. Clinical chorioamnionitis at term I: microbiology of the amniotic cavity using cultivation and molecular techniques. J Perinat Med 2015;43(1):19-36. doi: 10.1515/jpm-2014-0249

19. Aviram A, Quaglietta P, Warshafsky C, Zaltz A, Weiner E, Melamed $\mathrm{N}, \mathrm{Ng} \mathrm{E}$, Barrett J, Ronzoni S. The utility of ultrasound assessment in the management of preterm prelabor rupture of the membranes. Ultrasound Obstet Gynecol 2020;55(6):806-14. doi: 10.1002/ uog. 20403

20. Marcellin L, Anselem O, Guibourdenche J, De la Calle A, DeputRampon C, Cabrol D, Tsatsaris V. [Comparison of two bedside tests performed on cervicovaginal fluid to diagnose premature rupture of membranes]. J Gynecol Obstet Biol Reprod (Paris) 2011;40(7):651-6. doi: 10.1016/j.jgyn.2011.06.007

21. Musilova I, Pliskova L, Gerychova R, Janku P, Simetka O, Matlak $P_{\text {, }}$ Jacobsson B, Kacerovsky M. Maternal white blood cell count cannot identify the presence of microbial invasion of the amniotic cavity or intra-amniotic inflammation in women with preterm prelabor rupture of membranes. PLoS One 2017;12(12):e0189394. doi: 10.1371/ journal.pone.0189394

22. Kacerovsky M, Musilova I, Hornychova H, Kutova R, Pliskova L, Kosta $M$, Jacobsson B. Bedside assessment of amniotic fluid interleukin- 6 in preterm prelabor rupture of membranes. Am J Obstet Gynecol 2014;211(4):385.e1-9. doi:10.1016/j.ajog.2014.03.069

23. Vousden N, Chandiramani M, Seed P, Shennan A. Interleukin-6 bedside testing in women at high risk of preterm birth. J Matern Fetal Neonatal Med 2011;24(10):1301-4. doi: 10.3109/14767058.2011.558954

24. Musilova I, Andrys C, Holeckova M, Kolarova V, Pliskova L, Drahosova M, Bolehovska R, Pilka R, Huml K, Cobo T, Jacobsson B, Kacerovsky M. Interleukin- 6 measured using the automated electrochemiluminescence immunoassay method for the identification of intra-amniotic inflammation in preterm prelabor rupture of membranes. J Matern Fetal Neonatal Med 2020;33(11):1919-26. doi: 10.1080/14767058.2018.1533947

25. Erdemir G, Kultursay N, Calkavur S, Zekioglu O, Koroglu OA, Cakmak B, Yalaz M, Akisu M, Sagol S. Histological chorioamnionitis: effects on premature delivery and neonatal prognosis. Pediatr Neonatol 2013;54(4):267-74. doi: 10.1016/j.pedneo.2013.03.012

26. Redline RW, Faye-Petersen O, Heller D, Qureshi F, Savell V, Vogler C, Society for Pediatric Pathology PSAFINC. Amniotic infection syndrome: nosology and reproducibility of placental reaction patterns. Pediatr Dev Pathol 2003;6(5):435-48. doi: 10.1007/s10024-0037070-y

27. Salafia CM, Weigl C, Silberman L. The prevalence and distribution of acute placental inflammation in uncomplicated term pregnancies. Obstet Gynecol 1989;73(3 Pt 1):383-9.

28. Kim CJ, Romero R, Chaemsaithong P, Kim JS. Chronic inflammation of the placenta: definition, classification, pathogenesis, and clinical significance. Am J Obstet Gynecol 2015;213(4 Suppl):S53-69. doi: 10.1016/j.ajog.2015.08.041

29. Romero R, Yoon BH, Mazor M, Gomez R, Gonzalez R, Diamond MP, Baumann P, Araneda H, Kenney JS, Cotton DB. A comparative study of the diagnostic performance of amniotic fluid glucose, white blood cell count, interleukin-6, and gram stain in the detection of microbial invasion in patients with preterm premature rupture of membranes. Am J Obstet Gynecol 1993;169(4):839-51. doi: 10.1016/0002-9378(93)90014-a

30. Musilova I, Kutova R, Pliskova L, Stepan M, Menon R, Jacobsson B, Kacerovsky M. Intraamniotic Inflammation in Women with Preterm Prelabor Rupture of Membranes. PLoS One 2015;10(7):e0133929. doi: 10.1371/journal.pone.0133929

31. Morley JJ, Kushner I. Serum C-reactive protein levels in disease. Ann N Y Acad Sci 1982;389:406-18. doi: 10.1111/j.1749-6632.1982. tb22153.x

32. Cobo T, Jacobsson B, Kacerovsky M, Hougaard DM, Skogstrand K, Gratacos E, Palacio M. Systemic and local inflammatory response in women with preterm prelabor rupture of membranes. PLoS One 2014;9(1):e85277. doi: 10.1371/journal.pone.0085277 
33. Trochez-Martinez RD, Smith P, Lamont RF. Use of C-reactive protein as a predictor of chorioamnionitis in preterm prelabour rupture of membranes: a systematic review. BJOG 2007;114(7):796-801. doi: 10.1111/j.1471-0528.2007.01385.x

34. Stepan M, Cobo T, Musilova I, Hornychova H, Jacobsson B, Kacerovsky M. Maternal Serum C-Reactive Protein in Women with Preterm Prelabor Rupture of Membranes. PLoS One 2016;11(3):e0150217. doi: 10.1371/journal.pone.0150217

35. Kidokoro K, Furuhashi M, Kuno N, Ishikawa K. Amniotic fluid neutrophil elastase and lactate dehydrogenase: association with histologic chorioamnionitis. Acta Obstet Gynecol Scand 2006;85(6):669-74. doi: 10.1080/01443610600604432

36. Popowski T, Goffinet F, Batteux F, Maillard F, Kayem G. [Prediction of maternofetal infection in preterm premature rupture of membranes: serum maternal markers]. Gynecol Obstet Fertil 2011;39(5):302-8. doi: 10.1016/j.gyobfe.2010.11.006

37. Cassell GH, Waites KB, Watson HL, Crouse DT, Harasawa R. Ureaplasma urealyticum intrauterine infection: role in prematurity and disease in newborns. Clin Microbiol Rev 1993;6(1):69-87. doi:10.1128/cmr.6.1.69

38. Gupta A, Gupta A, Gupta S, Mittal A, Chandra P,Gill AK. Correlation of mycoplasma with unexplained infertility. Arch Gynecol Obstet 2009;280(6):981-5. doi:10.1007/s00404-009-1042-z

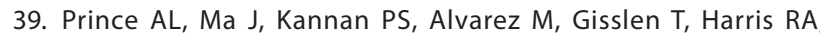
Sweeney EL, Knox CL, Lambers DS, Jobe AH, Chougnet CA, Kallapur $\mathrm{SG}$, Aagaard KM. The placental membrane microbiome is altered among subjects with spontaneous preterm birth with and without chorioamnionitis. Am J Obstet Gynecol 2016;214(5):627.e1-627e16. doi: 10.1016/j.ajog.2016.01.193

40. Sweeney EL, Kallapur SG, Gisslen T, Lambers DS, Chougnet CA, Stephenson SA, Jobe AH, Knox CL. Placental Infection With Ureaplasma species Is Associated With Histologic Chorioamnionitis and Adverse Outcomes in Moderately Preterm and Late-Preterm Infants. J Infect Dis 2016;213(8):1340-7. doi: 10.1093/infdis/jiv587

41. Pavlidis I, Spiller OB, Sammut Demarco G, MacPherson H, Howie SEM, Norman JE, Stock SJ. Cervical epithelial damage promotes Ureaplasma parvum ascending infection, intrauterine inflammation and preterm birth induction in mice. Nat Commun 2020;11(1):199. doi: 10.1038/s41467-019-14089-y

42. Amon E, Lewis SV, Sibai BM, Villar MA, Arheart KL. Ampicillin prophylaxis in preterm premature rupture of the membranes: a prospective randomized study. Am J Obstet Gynecol 1988;159(3):539-43. doi: 10.1016/s0002-9378(88)80002-4

43. Kwak HM, Shin MY, Cha HH, Choi SJ, Lee JH, Kim JS, Roh CR, Kim $\mathrm{JH}$, Oh SY. The efficacy of cefazolin plus macrolide (erythromycin or clarithromycin) versus cefazolin alone in neonatal morbidity and placental inflammation for women with preterm premature rupture of membranes. Placenta 2013;34(4):346-52. doi: 10.1016/j. placenta.2013.01.016

44. Lee J, Romero R, Kim SM, Chaemsaithong P, Yoon BH. A new antibiotic regimen treats and prevents intra-amniotic inflammation/ infection in patients with preterm PROM. J Matern Fetal Neonata Med 2016;29(17):2727-37. doi: 10.3109/14767058.2015.1103729

45. Lee J, Romero R, Kim SM, Chaemsaithong P, Park CW, Park JS, Jun JK, Yoon BH. A new anti-microbial combination prolongs the latency period, reduces acute histologic chorioamnionitis as well as funisitis, and improves neonatal outcomes in preterm PROM. J Matern Fetal Neonatal Med 2016;29(5):707-20. doi: 10.3109/14767058.2015.1020293

46. Gomez R, Romero R, Nien JK, Medina L, Carstens M, Kim YM, Espinoza J, Chaiworapongsa T, Gonzalez R, lams JD, Rojas I. Antibiotic administration to patients with preterm premature rupture of membranes does not eradicate intra-amniotic infection. J Matern Fetal Neonatal Med 2007;20(2):167-73. doi: 10.1080/14767050601135485.

47. Bianchi ME. DAMPs, PAMPs and alarmins: all we need to know about danger. J Leukoc Biol 2007;81(1):1-5. doi: 10.1189/jlb.0306164

48. Romero R, Chaiworapongsa T, Alpay Savasan Z, Xu Y, Hussein Y, Dong Z, Kusanovic JP, Kim CJ, Hassan SS. Damage-associated molecular patterns (DAMPs) in preterm labor with intact membranes and preterm PROM: a study of the alarmin HMGB1. J Matern Fetal Neonatal Med 2011;24(12):1444-55. doi: 10.3109/14767058.2011.591460

49. Cobo T, Kacerovsky M, Palacio M, Hornychova H, Hougaard DM, Skogstrand K, Jacobsson B. Intra-amniotic inflammatory response in subgroups of women with preterm prelabor rupture of the membranes. PLoS One 2012;7(8):e43677. doi: 10.1371/journal. pone.0043677

50. Tchirikov M, Zhumadilov Z, Winarno AS, Haase R, Buchmann J. Treatment of Preterm Premature Rupture of Membranes with Oligo-/Anhydramnion Colonized by Multiresistant Bacteria with Continuous Amnioinfusion and Antibiotic Administrations through a Subcutaneously Implanted Intrauterine Port System: A Case Report. Fetal Diagn Ther 2017;42(1):71-6. doi: 10.1159/000438483

51. Garcia-Munoz Rodrigo F, Galan Henriquez G, Figueras Aloy J, GarciaAlix Perez A. Outcomes of very-low-birth-weight infants exposed to maternal clinical chorioamnionitis: a multicentre study. Neonatology 2014;106(3):229-34. doi: 10.1159/000363127

52. Walker MW, Picklesimer AH, Clark RH, Spitzer AR, Garite TJ. Impact of duration of rupture of membranes on outcomes of premature infants. J Perinatol 2014;34(9):669-72. doi: 10.1038/jp.2014.73

53. Test G, Levy A, Wiznitzer A, Mazor M, Holcberg G, Zlotnik A, Sheiner E. Factors affecting the latency period in patients with preterm premature rupture of membranes. Arch Gynecol Obstet 2011;283(4):70710. doi: 10.1007/s00404-010-1448-7.

54. Goya M, Bernabeu A, Garcia N, Plata J, Gonzalez F, Merced C, Llurba E, Suy A, Casellas M, Carreras E, Cabero L. Premature rupture of membranes before 34 weeks managed expectantly: maternal and perinatal outcomes in singletons. J Matern Fetal Neonatal Med 2013;26(3):290-3. doi: 10.3109/14767058.2012.733779

55. Baser E, Aydogan Kirmizi D, Ulubas Isik D, Ozdemirci S, Onat T, Serdar Yalvac E, Demirel N, Moraloglu Tekin O. The effects of latency period in PPROM cases managed expectantly. J Matern Fetal Neonatal Med 2020;33(13):2274-83. doi: 10.1080/14767058.2020.1731465

56. Arora P, Bagga R, Kalra J, Kumar P, Radhika S, Gautam V. Mean gestation at delivery and histological chorioamnionitis correlates with early-onset neonatal sepsis following expectant management in pPROM. J Obstet Gynaecol 2015;35(3):235-40. doi: 10.3109/01443615.2014.958143

57. Stepan M, Cobo T, Maly J, Navratilova M, Musilova I, Hornychova $\mathrm{H}$, Jacobsson B, Kacerovsky M. Neonatal outcomes in subgroups of women with preterm prelabor rupture of membranes before 34 weeks. J Matern Fetal Neonatal Med 2016;29(14):2373-7. doi: $10.3109 / 14767058.2015 .1086329$ 